\title{
Egyenlő esélyekkel a munka világában? Esélyegyenlőség és jogvédelem a munkaerőpiacon
}

\author{
SUHAJDA CSILLA JUDIT ${ }^{1}$
}

\begin{abstract}
ABSZTRAKT
A tanulmány az esélyegyenlőség megvalósulását, valamint az ezzel kapcsolatos jogvédelem lehetôségeit vizsgálja a munkaerőpiacon. A kutatás célja, hogy feltárja, hogy melyek az esélyegyenlőség megsértésével kapcsolatos legjellemzőbb problémák az Egyenlő Bánásmód Hatóság joggyakorlata alapján. Meghatározható-e az, hogy mely típusú diszkrimináció jellemzô illetve, hogy jelenleg Magyarországon melyek a leghátrányosabbnak ítélt tulajdonságok a munkaerópiacon.

A feltárt összefüggések arra mutatnak rá, hogy jóllehet a törvényi háttér szabályozása jelentôs mértékben elösegítette az egyének jogtudatosságát e területen, de még több fórumra van szükség, hogy mérhető eredményeket érjünk el.
\end{abstract}

KULCSSZAVAK: munkaerőpiac, esélyegyenlőség, foglalkoztatás, diszkrimináció, tulajdonság

ABSTRACT

Equal opportunities at work?

Equal opportunities and legal protection in the labour market

The study examines the realization and the development oflegal protection of equal opportunities in the labour market. The purpose of the research is to identify the most common problems related to the violation of equal opportunities during the period since the Equal Treatment Authority began its work.

The study explores whether types of discrimination can be identified, which are the most prominent and which are the most disadvantaged characteristics of the labour market in Hungary today. The correlations discovered demonstrate that although regulation of the legal background has greatly facilitated the awareness of individuals in this field, there is a need to create further forums of discussion to achieve measurable results.

KEYWORDS: labour market, equal opportunities, employment, discrimination, property

${ }^{1}$ Tanársegéd, Szent István Egyetem Gazdaság- és Társadalomtudományi Kar. 


\section{TEMATIKUS TANULMÁNYOK - A munkaerőpiac gazdasági-társadalmi kérdései}

\section{Bevezetés}

Az esélyegyenlőség és a diszkrimináció problémája meghatározó jelenség korunk gondolkodásában, így az esélyegyenlőség biztosítása az Európai Unió egyik legfontosabb célja. Fontos azonban különbséget tennünk az esélyegyenlőség és az egyenlő bánásmód között. Az egyenlő bánásmód követelménye szerint senkit sem lehet tulajdonságai, vagy valamely csoporthoz való tartozása alapján diszkriminálni (Dajnoki et al. 2016). Az egyenlő bánásmód elve azonos a diszkrimináció, azaz a hátrányos megkülönböztetés tilalmával. „Az egyenlőség a demokrácia alapkövetelményének minősíthető. Ez az egyenlőség azonban jogi értelemben vett egyenlőséget jelent: a társadalom minden tagjának emberként és polgárként egyaránt egyenlőnek kell lennie, azaz egyenlőnek a törvény elött, egyenlönek mind politikai, mind szociális jogai tekintetében." (Neményi et al. 2013: 86)

Az esélyegyenlőség az egyenlő hozzáférés azonos módon való biztosítását, azaz az egyenlő bánásmódot jelenti (Farkas et al. 2011). Másképpen fogalmazva az arra való törekvés, hogy bárki számára elérhető lehetőség legyen bármilyen társadalmi cél elérése, ha annak érdekében kellő erőfeszítéseket tesz. A valódi esélyegyenlőség létrejöttéhez tehát szükséges olyan feltételek megteremtése, amelyek támogatottan biztosítják a hozzáférést.

Az esélyegyenlőség előmozdítása konkrét, a hátrányok kiegyenlítését segítő intézkedések végrehajtásával érhető el (Tardos 2015). A területet érintő szabályozásnak ennek megfelelően az a feladata, hogy olyan keretet biztosítson, amelyek a közösségi erőforrások leghatékonyabb felhasználását teszik lehetővé.

\section{Az esélyegyenlőség jogi keretei}

Az egyenlő bánásmód követelménye, azaz a hátrányos megkülönböztetés, diszkrimináció tilalma egyes, Magyarország által is elfogadott nemzetközi egyezményekben, valamint számos hazai törvényben már évtizedek óta szerepel. A nemzetközi jogi dokumentumok többnyire nem általánosságban rendelkeznek az egyenlő bánásmód követelményéről, hanem egy-egy meghatározott tulajdonság (faji, nemi hovatartozás stb.) vonatkozásában deklarálják a megkülönböztetés tilalmát.

A nemzetközi egyezmények közül kiemelkedik A faji megkülönböztetés valamennyi formájának kiküszöböléséről New Yorkban 1965. december 21-én elfogadott ENSZ-egyezmény, valamint a 2008. május 2-án hatályba lépett, „A fogyatékossággal élő személyek jogairól" szóló nemzetközi egyezmény, amely szintén az Egyesült Nemzetek égisze alatt jött létre.

A munka világát érintő szabályok sorában az ENSZ Nemzetközi Munkaügyi Szervezetének (ILO) 1951-ben meghozott 100. számú egyezménye, „A férfi és női munkaerőnek egyenlő értékü munka esetén járó egyenlő díjazásáról", hosszú ideig a bérezéssel kapcsolatos legfontosabb hivatkozási alapot jelentette. Ennek a to- 


\section{TEMATIKUS TANULMÁNYOK - A munkaerőpiac gazdasági-társadalmi kérdései}

vábbfejlesztéseként született meg a 111. sz. ILO egyezmény „A foglalkoztatásból és a foglalkozásból eredő hátrányos megkülönböztetésről” 1958-ban, amely felszólítja az egyezményhez csatlakozókat a foglalkozáshoz, képzéshez és a megfelelő munkafeltételekhez való hozzájutásban érvényesülő, faj, bőrszín, nem, vallás, politikai vélemény, nemzetiség és társadalmi helyzet alapján történő megkülönböztetés megszüntetésére és az egyenlő esélyek és elbánás elősegítésére.

Az európai egyesítési folyamatban az esélyegyenlőségi kérdés eredetileg nem tartozott az Európai Gazdasági Közösség (EGK) célkitűzései közé. Ennek ellenére, a közös társadalompolitikáról már az 1957-es, az EGK-t alapító Római Szerződés is külön fejezetben rendelkezett, a társadalmi és szociális kérdéseket csupán a gazdasági együttműködés előrehaladásával összefüggésben kívánták rendezni. Elsőként, az európai integráció kezdeti időszakában (1957 és 1972 között) a munkaerő szabad áramlásának megteremtését segítő szabályozások születtek meg, a társadalmi jogharmonizáció kezdete viszont az 1972-1986 közötti időszakra tehető. Ennek köszönhető, hogy az európai integráció szervei az esélyegyenlőség megteremtésének programjaként 1975 óta számos irányelvet léptettek hatályba a területen. Az Európai Bizottság több fontos dokumentumot bocsátott ki, amelyek hosszabb távra adnak cselekvési terveket, programokat magának az Uniónak és tagállamainak is. Vannak rendkívüli jelentőségű stratégiák, mint például „A nemek közötti esélyegyenlőség közösségi keretstratégiája 2001-2005”, az „Európai Foglalkoztatási Stratégia”, vagy a „Lisszaboni Stratégia”, amelyek hosszú távú célkitűzéseket fogalmaztak meg a nemek közötti esélyegyenlőség előmozdításáról.

Az Amszterdami Szerződés (1999) 6. cikke a nemen, faji vagy etnikai származáson, valláson vagy meggyőződésen, fogyatékosságon, koron vagy szexuális irányultságon alapuló megkülönböztetés tilalmáról szól. A 119. cikkely már arról rendelkezik, hogy a nők és a férfiak egyenlő értékű munkáért egyenlő díjazást kapjanak.

Az Európai Tanács 2000. december 7. és 9. közötti, nizzai ülésén elfogadott Alapvető jogok chartájának 23. cikkelye szól a férfiak és nők közötti egyenlőségről. „A férfiak és nők egyenlőségét minden területen, így a foglalkoztatás, munkavégzés és a bérezés területén is biztosítani kell. Az egyenlőség elve nem akadályozhatja az alulreprezentált nem számára különleges előnyöket biztosító rendelkezések fenntartását vagy meghozatalát." (Barakonyi 2015: 41) A 26. cikk garantálja a fogyatékos személyek jogát az önállóságuk, társadalmi és foglalkozási beilleszkedésük, valamint a közösség életében való részvételük biztosítását célzó intézkedésekre.

Az Európai Bizottság 2004 májusában tette közzé az „Esélyegyenlőség és diszkrimináció-mentesség a kibővített Európai Unióban” című Zöld könyvét, amelyben konzultációra hívta az érintett szervezeteket. Közösségi szinten az Európai Bizottság Foglalkoztatási, Szociális és Esélyegyenlőségi Főigazgatósága arra törekszik, hogy tevékenysége nyomán egyre több és egyre jobb munkahely álljon a munkavállalók rendelkezésére, valamint hogy az Unió befogadó és egyenlő esélyeket biztosító társadalommá váljon. 


\section{TEMATIKUS TANULMÁNYOK - A munkaerőpiac gazdasági-társadalmi kérdései}

Az EU Bizottság 2003-as Esélyegyenlőségi Cselekvési Terve alapján, 2008-ban konkrét ajánlások születtek arra, hogy a tagállamok milyen intézkedésekkel - rugalmas foglalkoztatási rendszerek, támogatott foglalkoztatás, szociális gazdaság, aktív befogadást támogató szolgáltatások, bértámogatások, a munkahelyek adaptációja, a támogató technológiák és a személyes segítségnyújtás - ösztönözzék a fogyatékos emberek munkaerőpiaci integrációját és re-integrációját.

Az EU másodlagos közösségi jogszabályai közül a 2000/78/EK irányelv arról szól, hogy diszkriminációhoz vezet, ha a munkahelyeken nem történnek meg olyan átalakítások, mint az akadálymentesítés, vagy a munkaeszközök alkalmassá tétele arra, hogy azokat a fogyatékos dolgozók is használják. A szabályozás figyel arra, hogy a munkáltatónak megérje a munkahely átalakítása. Ezért csak a munkához jutás, a munkában és képzésben való részvétel és a szakmai előmenetel ésszerü feltételei biztosításának kötelezettségét említi, kivéve, ha ez a munkáltatónak aránytalanul nagy terhet jelentene (Niederfiringer 2013).

Az egyenlő bánásmód követelményének szabályozása Magyarországon három szintű. Az Alaptörvény általános érvénnyel mondja ki a hátrányos megkülönböztetés tilalmát, az egyenlő bánásmódról és az esélyegyenlőség előmozdításáról szóló törvény a jogrendszer egésze számára ad részletesebb útmutatást a követelmény értelmezéséhez, és számos jogszabály (Munka Törvénykönyve, egészségügyi törvény) utal az esélyegyenlőségi törvényre és állapít meg további, csak az adott területen érvényes szabályokat.

A területet átfogóan szabályozó, az egyenlő bánásmódról és az esélyegyenlőség előmozdításáról szóló 2003. évi CXXV. törvény (Ebktv.) 2004. január 27-én lépett hatályba. Az Esélyegyenlőségi törvény egyrészt felsorolja, hogy melyek azok a „tulajdonságok", amelyek alapján tiltott a hátrányos megkülönböztetés, másrészt igen széles körre terjeszti ki a diszkrimináció tilalmát. Ide sorolható a nem, az életkor, az egészségi állapot, a vallás, vagy a politikai hovatartozás. A tulajdonságnak nem kell ténylegesen fönnállnia, így a hátrányos megkülönböztetés akkor is megállapítható, ha valakit vélt tulajdonsága miatt ér diszkrimináció. Az érintett tulajdonságokat a törvény csupán példálózó jelleggel sorolja fel, ezeken túl ugyanis tiltja a más hasonló tulajdonság, helyzet vagy jellemző alapján megvalósuló, az egyenlő bánásmódot sértő magatartásokat is. A törvény alapállása, hogy „elismeri minden ember jogát, hogy egyenlő méltóságú személyként élhessen”, szándéka pedig az, hogy „hatékony jogvédelmet biztosítson a hátrányos megkülönböztetést elszenvedők számára" (Ebktv. preambulum).

A törvény szellemét és betűjét követve a foglalkoztatók feladata, hogy tiszteletben tartsák a munkatársak emberi értékeit, méltóságát, egyediségét. A szervezetek feladata, hogy érdekeiket a munkatársak érdekeivel összhangban fogalmazzák meg. Olyan munkafeltételeket, munkakörülményeket, munkahelyi légkört alakítsanak ki, amely a szervezeti kultúra részeként a törvényben megfogalmazott alapvető értékeknek a kialakításához, megőrzéséhez és megerősítéséhez hozzájárulnak. A tör- 


\section{TEMATIKUS TANULMÁNYOK - A munkaerőpiac gazdasági-társadalmi kérdései}

vényi elvárások teljesítése azért is aktuális és fontos, mert a munkahely veszélyes üzem, ahol az alkalmazottak fizikai és lelki támadásoknak vannak kitéve (Mihály 2003).

\section{AZ ESÉLYEGYENLŐSÉG GARANCIÁI}

Hazánkban az egyenlő bánásmód követelményének megsértése miatt az Egyenlő Bánásmód Hatósághoz (EBH) lehet fordulni, ahol közigazgatási eljárás keretében kivizsgálják a bejelentés tartalmát. A Hatóság legfontosabb feladata a törvény értelmében, hogy kérelem alapján, illetve egyes esetekben hivatalból vizsgálatot folytasson annak megállapítására, hogy megsértették-e az egyenlő bánásmód követelményét, majd a vizsgálat alapján határozatot hozzon (Gregor - Pásztor 2016).

Az Egyenlő Bánásmód Hatóság általános hatáskörében a védett tulajdonsággal összefüggésben megvalósuló hátrányos megkülönböztetéseket vizsgálja, miközben valódi pozitív hatások elérésére törekszik a diszkriminációs folyamatokban: azok felismerését, illetve megelőzését a jogalkalmazás mellett szakmai információkkal és kiadványokkal támogatja. Olyan panaszosok ügyében jár el, akiket diszkrimináció, azaz hátrányos megkülönböztetés ér (Neményi et al. 2017).

2003. évi CXXV. törvény meghatározta az egyenlő bánásmód követelménye megsértésének minősülő öt magatartást, azaz a diszkrimináció típusait. Ezek a közvetlen hátrányos megkülönböztetés, a közvetett a hátrányos megkülönböztetés, a zaklatás, a jogellenes az elkülönítés, valamint a megtorlás. A sérelmet szenvedett természetes személy (személyesen vagy meghatalmazottja útján), jogi személy vezetője vagy meghatalmazottja, érdekképviseleti szervezet vagy közérdekű igényérvényesítő a hatósághoz intézett kérelemmel kezdeményezheti az eljárást.

A hatóság egyenlőbánásmód-referensi hálózata a jogorvoslati lehetőségeket megyei és járási szinteken is közvetlenül elérhetővé tette. Létjogosultságát jelzi, hogy a hálózat tagjait évek óta keresik fel kérdéseikkel, problémáikkal az érintettek.

Az Ebktv. szerint a helyi önkormányzat, valamint a többcélú kistérségi társulás öt évre szóló helyi esélyegyenlőségi programot köteles elfogadni. A helyi esélyegyenlőségi programban helyzetelemzést kell készíteni a hátrányos helyzetű társadalmi csoportok oktatási, lakhatási, foglalkoztatási, egészségügyi és szociális helyzetéről, illetve meg kell határozni a helyzetelemzés során feltárt problémák komplex kezelése érdekében szükséges intézkedéseket.

Az Ebktv., valamint a Munka törvénykönyvéről szóló 2012. évi I. törvény szabályozása alapján az 50 főnél több munkavállalót foglalkoztató állami vagy önkormányzati intézményeknek, valamint az állami, illetve önkormányzati többségi tulajdonban álló gazdasági társaságoknak munkahelyi esélyegyenlőségi tervet kell készíteniük. A szabályozás alapján az esélyegyenlőségi tervvel kapcsolatban öt, a munkáltatóval munkaviszonyban álló hátrányos helyzetű munkavállalói csoportot 


\section{TEMATIKUS TANULMÁNYOK - A munkaerőpiac gazdasági-társadalmi kérdései}

emel ki. Ezek a nők, a negyven évnél idősebb munkavállalók, a romák, a fogyatékos személyek, valamint a két vagy több tíz éven aluli gyermeket nevelő munkavállalók vagy tíz éven aluli gyermeket nevelő egyedülálló munkavállalók (Garadnay et al. 2009). Tartalmában leginkább a megfelelő munkakörülmények biztosítását, az egyenlő bánásmód érvényesítésével kapcsolatos eljárási rendet, valamint a munkáltatók az esélyegyenlőségre vonatkozó, az adott évre megfogalmazott céljait, a célok eléréséhez szükséges eszközöket (különösen a képzési, munkavédelmi, valamint a munkáltatónál rendszeresített, a foglalkoztatás feltételeit érintő bármely programokat) határozza meg rendezni. Azon szervezet esetében, amely a jogszabály által a tervkészítésre kötelezett körbe sorolható, a terv hiánya esetén, illetve az egyenlő bánásmód követelményének megsértése vagy jogsértő gyakorlat folytatása kapcsán az Egyenlő Bánásmód Hatósága bírságot szabhat ki. Ez együtt járhat a szervezet számára megítélt közpénzek folyósításának meghatározott időre történő felfüggesztésével (Juhász - Maticsákné 2014).

Mindezeken felül az egyes munkahelyek esélyegyenlőség biztosításának és előmozdításának eszközei lehetnek a belső szabályzatok és iránymutatások, illetve a tematikus munkahelyi tréningek. Ezek a megoldások segíthetik a munkáltatókat abban, hogy a vonatkozó jogszabályi követelményeknek megfeleljenek. Hátrányuk viszont az, hogy legtöbbször az ilyen szabályzatok, iránymutatások és tréningek a munkáltató egyoldalú döntésén alapulnak és azok kidolgozásában a munkavállalók (különösen a hátrányos helyzetű munkavállalói csoportok) véleménye nem tükröződik. Mégis az esélyegyenlőségi terv elkészítése alternatívát jelenthet a munkáltatóknak, hogy az esélyegyenlőséghez kapcsolódó célokat megvalósítsák. A munkáltató és a munkáltatónál képviselettel rendelkező szakszervezet, valamint (szakszervezet hiányában) az üzemi tanács együttesen fogadhatja el a munkahelyi esélyegyenlőségi tervet. Az esélyegyenlőségi terv kizárólag határozott időre szólhat és ebben olyan munkáltatói intézkedések és programok rögzíthetők, amelyek a hátrányos helyzetű csoportok esélyegyenlőségének elősegítését célozzák.

Az egyes szabályozásokon és munkahelyi intézkedéseken túl ma már számos hazai és nemzetközi szervezet, hálózat foglalkozik a témával, amelyek kutatással, tanácsadással és érdekképviselettel támogathatják az esélyegyenlőség megteremtését. Ide sorolható az Equinet - Egyenlőségi Testületek Európai Hálózata (European Network of Equality Bodies), az EIGE - Nemek Közötti Egyenlőség Európai Intézete (European Institute for Gender Equality), a FRA - az Európai Unió Alapjogi Ügynöksége (European Union Agency for Fundamental Rights) és a ECRI - Rasszizmus és Intolerancia Elleni Európai Bizottság (European Commission against Racism and Intolerance) szervezete is, amelyek mind ezen célok mentén szervezik tevékenységüket (Gregor - Pásztor 2016, 2017). 


\section{TEMATIKUS TANULMÁNYOK - A munkaerőpiac gazdasági-társadalmi kérdései}

\section{Esélyegyenlőtlenségek a foglalkoztatás területén}

Az esélyegyenlőség érvényesítése a foglalkoztatásban valamennyi csoport számára kiemelt feladat. A halmozottan hátrányos helyzetű munkavállalók esetében azonban különösen fontos az egyenlő hozzáférés biztosításán túl az olyan támogató lépések, szolgáltatások tervezése és megvalósítása, amelyek csökkentik meglévő hátrányaikat és biztosítják hozzáférésüket azokhoz a lehetőségekhez, amelyekkel később sikeresebbek, eredményesebbek lehetnek a munkaerőpiacon.

A munkaerőpiacon leginkább azok a csoportok érintettek a diszkriminációban, amelyek valamilyen speciális tulajdonságuk miatt a hátrányos helyzetű csoportokhoz sorolhatók. A hátrányos helyzetet sokan és sokféleképpen értelmezik, a vonatkozó szakirodalom is számos aspektusból vizsgálja a kérdést. Általánosan azt mondhatjuk, hogy azokat az embereket sorolhatjuk a hátrányos helyzetűek közé, akiket társadalmi, családi helyzetük vagy az előítéletek korlátozzák lehetőségeik kibontakoztatásában, illetve, akik rendezett körülmények között élnek ugyan, de személyes okokból (pl. személyiségéből adódóan vagy az egészségkárosodással élők) nem, vagy csak nehezen integrálódnak a társadalomba.

A munkaerőpiacon számos hátrányos helyzetű csoport található, amelyek speciális jellemzőkkel bírnak. A magyar kutatók egymástól eltérő csoportokat jelölnek meg a munkaerőpiac szempontjából hátrányos helyzetűnek. Őry (2005) az alacsony végzettségűeket, a bevándorlókat (menekülteket), a megváltozott munkaképességűeket (fogyatékossággal élő embereket), valamint a cigányságot tartja ehhez a gyűjtőfogalomhoz tartozónak. Halmos (2005) a pályakezdőket, az idősebbeket, a tartós munkanélkülieket, a nőket, a roma népességet és az egészségkárosodottakat sorolja ide. Cserné (2006) munkatársaival munkaerőpiaci aspektusból hátrányos helyzetünek írja le az alacsony iskolázottságúakat, a tartós munkanélkülieket, a megváltozott munkaképességűeket, a gyermekgondozási ellátásban részesülőket, a 45 év felettieket és a korkedvezményes nyugdíjasokat. Kenderfi (2012) szerint a hátrányos helyzetben a szociális tartalom hangsúlyos, itt a társadalmi érvényesülés áll célként a középpontban. A hátrányos helyzet azzal a veszéllyel jár, hogy az egyes ember nem tudja optimálisan kibontakoztatni és kihasználni meglévő adottságait. Ennek alapján azt mondhatjuk, hogy hátrányos helyzetű az a személy, akinek életfeltételeiből, körülményeiből következő társadalmi karrierlehetősége nem biztosított (Visztenvelt et al. 2014).

A foglalkoztatáspolitika aspektusából a fentieket röviden úgy lehet összefoglalni, hogy hátrányos helyzetűek azok, akiknek munkaerőpiaci esélyei az átlagnál alacsonyabbak (Cserné 2006). Fontos ugyanakkor megjegyeznünk, hogy a munkaerőpiacon hátrányos helyzetűnek számítanak az olyan egyéb speciális hátrányokkal és problémákkal küzdő csoportok is, mint a hajléktalanok, a gyermekvédelmi gondoskodásból kikerülők, a szabadságvesztés büntetésüket töltő fogva tartott és büntetés-végrehajtási intézményből szabaduló személyek, továbbá a szenvedélybetegek, 


\section{TEMATIKUS TANULMÁNYOK - A munkaerőpiac gazdasági-társadalmi kérdései}

illetve pszichés betegséggel küzdő emberek csoportjai, akik számára alapvető feltételek hiányoznak ahhoz, hogy valós esélyük legyen a foglalkoztatásban való részvételre. (Kenderfi 2012) Kiszolgáltatott helyzetüket tovább növeli a munkáltatók részéről a velük szemben megnyilvánuló magas fokú előítélet is.

A munkaerőpiacon több tényező is vezethet külön-külön vagy együttesen foglalkoztatási diszkriminációhoz. Ilyen tényező lehet a nemzeti vagy etnikai hovatartozás, az életkor, a nem, az egészségi állapot, a lakóhely vagy a családi állapot.

A foglalkozási diszkrimináció legtipikusabb formája az új munkaerő felvételénél, kiválasztásánál jelentkezik. A felvételnél megnyilvánuló diszkrimináció lehet nyílt, közvetlen és rejtett, illetve közvetett is. Az esélyegyenlőség különböző szintjei közül itt a foglalkoztatáshoz való egyenlő jog csorbul. (Lipták et al. 2018)

Foglalkozási diszkrimináció érvényesülhet a vállalaton belüli előmenetel, illetve a munkaköri besorolás terén is. (Juhász et al. 2014) Az esélyegyenlőség szempontjából itt az a kérdés, hogy a különböző társadalmi csoportoknak mennyiben van esélyük, hogy a szervezeten belül megszerezzék azt a pozíciót, amelyet szeretnének, mennyiben van esélye az adott csoport képviselőjének a vágyott munkakör elérésére. Fontos azonban azt is tudni, hogy nem csak a felvételnél vagy az előremenetelnél, hanem a szervezetek elbocsátási döntéseinél is felléphet nyílt vagy rejtett diszkrimináció (Tardos 2015).

A munkahelyi esélyegyenlőség megteremtése elsősorban szervezeti önelemzésen alapul (Simonovits et al. 2013). A helyzetkép megalkotásába beletartozik a hátrányos helyzetű csoportokba tartozók (pl. nők, kisebbséghez tartozók, 45 év felettiek, fogyatékkal élők, kisgyermeket nevelők) feltérképezése a szervezet különböző területein. A sikeres programok ugyanis csak a jelen állapotok, igények ismeretéből indíthatók ki.

Törekedni kell, hogy az egyenlő esélyek biztosítása a teljes munkaviszony fennállása alatt megvalósuljon (Farkas et al. 2011). Ennek főbb pontjai a következők:

- Álláshirdetés: A hirdetések megfogalmazásakor törekedni kell arra, hogy az elvárások szigorúan a munkakör betöltéséhez kötődjenek. Így az olyan hirdetések, mint „Fiatal dinamikus munkatársat keresünk...”, törvénysértők.

- Jelentkezési formanyomtatványok: a formanyomtatványok esetében az a legcélravezetőbb, ha csak a munkakör szempontjából fontos készségekre, tapasztalatokra kérdez rá. Tilos megkérdezni a jelentkezők korát vagy nemét, kivéve, ha ennek valamely jogszabályi rendelkezés miatt van jelentősége. A fényképek csatolásának kívánalma lehetőséget teremt diszkriminációra a jelentkező kora vagy bőrszíne alapján, ezért ezt jobb elkerülni.

- Felvételi beszélgetés: A felvételi elbeszélgetés során óriási szerepet játszanak a jelentkezőkről szerzett benyomások. Ugyanakkor fontos tudnunk azt is, hogy ilyenkor fordul elő a leggyakrabban diszkrimináció is. Ezért indokolt, hogy az interjúzást több személy végezze, akik egységes kérdéseket tesznek fel a jelölteknek. Lényeges az is, hogy a kérdések megfogalmazása se adjon okot 


\section{TEMATIKUS TANULMÁNYOK - A munkaerőpiac gazdasági-társadalmi kérdései}

közvetlen hátrányos megkülönböztetésre. Ilyenek lehetnek különösen a magánéletre, párkapcsolatra, családi életre, tervezett gyermekvállalásra, szexuális szokásokra, lakóhelyre, származásra, vallási vagy politikai meggyőződésre, politikai események megítélésére, vagyoni helyzetre, egészségi állapotra vonatkozó kérdések.

- Bérezés, juttatás: az „egyenlő munkáért egyenlő bért” Alaptörvényi szinten is rögzítésre került hazánkban, mégis a gyakorlat arra enged következtetni, hogy ez a feltétel nem mindenütt valósul meg teljes mértékben (Cseres - Gergely 2018).

- Betanítás, beillesztés támogatása: Az új munkatárs betanításának folyamata sokszor hosszú időt vesz igénybe, azonban az nemcsak a szakma, hanem a szervezet megismerését is magában hordozza. Ezért hasznos lehet a munkahelyi patrónusok/mentorok kijelölése a befogadás és a beilleszkedés segítésére.

- Képzések, továbbképzések: A hatékony szervezet számára elengedhetetlen a jól képzett, felkészült munkaerő, azonban gyakran megesik, hogy bizonyos csoportok rendszeresen kimaradnak a továbbképzésekben résztvevők köréből (Tardos 2015). A képzési tervek elkészítésekor, a képzések szervezésekor és meghirdetésekor érdemes külön figyelmet szentelni arra, hogy azok széles kör számára elérhetők legyenek.

- Atipikus munkavégzési formák biztosítása: Számos formája és típusa létezik (pl. részmunkaidő, osztott munkakör, távmunka), azonban a mai napig problémát jelent, hogy a flexibilis munkavállalási formák alkalmazásakor fennáll a törékeny foglalkoztatás veszélye (Hárs 2012): ebben az esetben a munkavállaló sokszor kiszolgáltatottabb a vállaltvezetésnek.

A munkahelyi esélyteremtés megvalósítását számos tényező befolyásolja. Ide sorolható a vezetők és a munkavállalók elkötelezettsége, a vállalati kommunikáció, a tiszta és átlátható célok megfogalmazása, valamint a folyamatok és eredmények mérése, folyamatos utánkövetése (Dajnoki et al. 2016).

Mindezek alapján látható, hogy a terület igen komplex és széles spektrumot ölel fel, és noha jogi és intézményi feltételei kiépítettek, a téma összetettsége és érzékenysége számos veszélyt és visszaélési lehetőséget hordoz magában. 
www. metszetek.unideb.hu

\title{
TEMATIKUS TANULMÁNYOK - A munkaerőpiac gazdasági-társadalmi kérdései
}

\section{Diszkriminatív munkaerőpiaci bejelentések számának és jellegének alakulása}

\author{
A VIZSGÁLATI MINTA ÉS MÓDSZER
}

2005. február elsejével kezdte meg munkáját az Egyenlő Bánásmód Hatóság, feladata a diszkriminációs ügyekben benyújtott panaszok, bejelentések kivizsgálása. A hatóság a közigazgatási eljárás szabályai szerint folytat vizsgálatot, munkáját az országos lefedettségű referensi hálózat segíti. A hatóság a diszkriminatív magatartások megelőzését, felismerését, a diszkriminációmentes szemlélet elsajátítását a jogalkalmazás mellett szakmai publikációkkal, programokkal és információs kiadványokkal támogatja (Gregor- Pásztor 2016).

A tanulmányban az Egyenlő Bánásmód Hatóság munkájának kezdete óta minden évben megjelenő „Éves tájékoztató az Egyenlő Bánásmód Hatóság tevékenységéről” című, 2005, 2010 és 2015 éves jelentései alapján dokumentumelemzés módszerével vizsgáltam a hatóság tevékenységét. A jelentések sajátossága, hogy azok nem tartalmazzák az összes ügy leírását, inkább több szempont szerint összegzik azokat és az adott évben legmeghatározóbb területekről példaszerűen mutatnak be eseteket. A választott módszer segítségével 5 éves periódusok távlatán keresztül lehetőség nyílik megvizsgálni a beadványok mennyiségi és tartalmi alakulását, valamint a hatóság tevékenységeinek jellegét, amely alapján következtethetünk az állampolgári jogtudatosságra a területen.

\section{EREDMÉNYEK}

a) A beadványok számának alakulása $(2005,2010,2015)$

A Hatóság 2005-ben kezdte meg tevékenységét, jelentőségét jól mutatja, hogy már múködésének első évében is jelentős számú beadványt nyújtottak be a szervezethez (1. ábra).

2005-ben 491 beadvány érkezett a hatósághoz, amelyből 144 (29,3 \%) érdemi határozattal zárult, amelyből 9 (1,83\%) esetben állapította meg a Hatóság az egyenlő bánásmód követelményének megsértését. A Hatóság 2005-ben 103 (20,97\%) esetben hozott elutasító határozatot, az elutasítások döntő hányadának oka a Hatóság hatáskörének hiányára vezethető vissza.

A vizsgált évben érkezett beadványok alapján összesen $18^{2}$ (3,66\%) esetben állapított meg jogsértést a Hatóság. A marasztaló határozatok közül 5 esetben bírság kiszabására, 5 esetben a határozat nyilvánosságra hozatalára, a fennmaradó esetek-

${ }^{2}$ A 18 esetből 9 esetben még 2005 folyamán, a maradék 9 esetben 2006. június 30-ig született elmarasztaló határozat. 
www. metszetek.unideb.hu

\section{TEMATIKUS TANULMÁNYOK - A munkaerőpiac gazdasági-társadalmi kérdései}

ben pedig a jogsértés megszüntetésére, illetve a jövőbeni jogsértéstől való eltiltásra került sor.

\section{1. ábra. Az Egyenlő Bánásmód Hatóság}

2005, 2010 és 2015. évi tevékenységének összegzése (db)

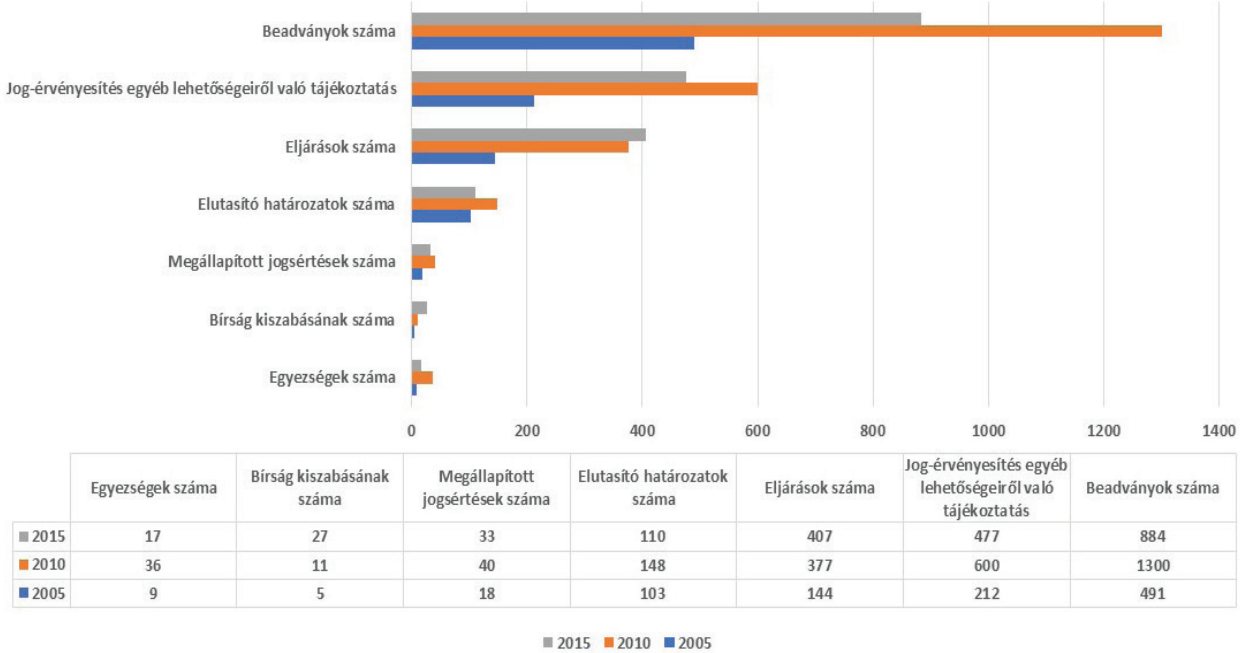

Forrás: Saját feldolgozás az EBH 2005., 2010. és 2015. évi jelentésének adatai alapján, 2018

Az Egyenlő Bánásmód Hatósághoz 2010. évben mintegy 1300 ügyben fordultak magánszemélyek, szervezetek és munkáltatók képviselői tájékoztatásért és jogi segítségért. Ezen ügyek közül a Hatóság 2009-ben 377 (29 \%) ügyben indított hatósági eljárást, ezek közül 40-ben állapított meg jogsértést, 244 (18,7\%) ügy pedig 2011-ben is folytatódott.

2015-ben a 884 beadvány érkezett a szervezethez, az eljárások során (407db) $33(8,1 \%)$ esetben állapított meg a Hatóság jogsértést, 110 alkalommal (27\%) pedig elutasító határozat született.

\section{b) A megállapított diszkriminációk típusai}

2005-ben a Hatóság által vizsgált jogsértések körében a diszkrimináció fajtái szerint 36 esetben közvetlen hátrányos megkülönböztetést, 6 esetben zaklatást, valamint 1-1 esetben közvetett hátrányos megkülönböztetést, jogellenes elkülönítést, illetve megtorlást állapított meg. 11 ügy esetében döntött úgy a Hatóság, hogy bizonyítható 
a szolgáltatásokkal kapcsolatos hátrányos megkülönböztetés a kérelmező egyéb helyzete, életkora, etnikai hovatartozása, fogyatékossága, nemzetisége, bőrszíne, egészségi állapota, vagyis az ún. védett tulajdonsága miatt.

2010-ben az alkalmazott szankciókat tekintve a kiszabott bírságok mintegy felét - 14400000 forintot - a Hatóság a munkáltatóval szemben szabta ki. A Hatóság mintegy 600 esetben válaszlevelet küldött ki más jogérvényesítési lehetőségről. 148 ügyben született elutasító határozat, többségükben azért, mert az eljárás alá vont bizonyította, hogy nem tett különbséget a panaszossal összehasonlítható helyzetben lévők javára. Fontos mindezek mellett azt is kiemelni, hogy a kérelmet elutasító határozatok mintegy $80 \%$-a a foglalkoztatás területével összefüggő panaszok nyomán született. Az elutasítás indoka jellemzően a kérelmező által megjelölt védett tulajdonság, valamint a sérelem és a védett tulajdonság közötti összefüggés hiányán alapult.

2015-ben a beadványok száma és ezzel párhuzamosan az eljárások, bírságok száma a 2010 évihez képest kis mértékben csökkent, ahogy az elutasított beadványok száma is. Az Egyenlő Bánásmód Hatóság 33 esetben állapította meg, hogy sérült az egyenlő bánásmód követelménye és 17 esetben született egyezséget jóváhagyó határozat. Ez a Hatósághoz érkezett beadványok tudatosságát és helyességét is jelezheti. Minderre a szervezet tudatos kommunikációja is hatást gyakorolhatott, hiszen az EBH 2015. január 1-től a Kommunikációs és Partnerségi Főosztály létrehozásával biztosította az intézményi kommunikáció pozitív hatásait a diszkriminációs folyamatok tudatosításában és megelőzésében. A fóosztály az egyenlő bánásmód követelményének tudatosítását és a hátrányos megkülönböztetés eseteinek megelőzését az információszolgáltatás koordinálásával és partnerségi hálózatépítéssel támogatja.

\section{c) A beadványok tartalmi megoszlása}

2005-ben a benyújtott kérelmek nagyrészt a munka világával, főleg a romák munkavállalásával, az 50 év felettiek, a nők, a gyermeket vállalók és a fogyatékossággal élők foglalkoztatásával, elbocsátásával voltak kapcsolatosak. 2005-ben leginkább a roma lakosságot érintette a szolgáltatások megtagadása a kereskedelmi-vendéglátóipari egységekben, a fogyatékkal élőket pedig az egyéb szolgáltatásokhoz történő hozzáférésük kapcsán. Több bejelentés érkezett az oktatással, a hátrányos helyzetű tanulók elkülönítésével, magántanulóvá nyilvánításával kapcsolatosan is. Jellemző volt még az EBH megalakulásának évében az is, hogy többen, akik a hátrányos megkülönböztetés miatt a Hatósághoz fordultak, visszavonták a kérelmüket, nevük és beosztásuk titokban tartását kérték. Ez esetben természetesen nem lehetett lefolytatni a vizsgálatot (2. ábra). 


\section{TEMATIKUS TANULMÁNYOK - A munkaerőpiac gazdasági-társadalmi kérdései}

2. ábra. A jogsértéssel végződő ügyek megoszlása a védett tulajdonságok szerint (\%)

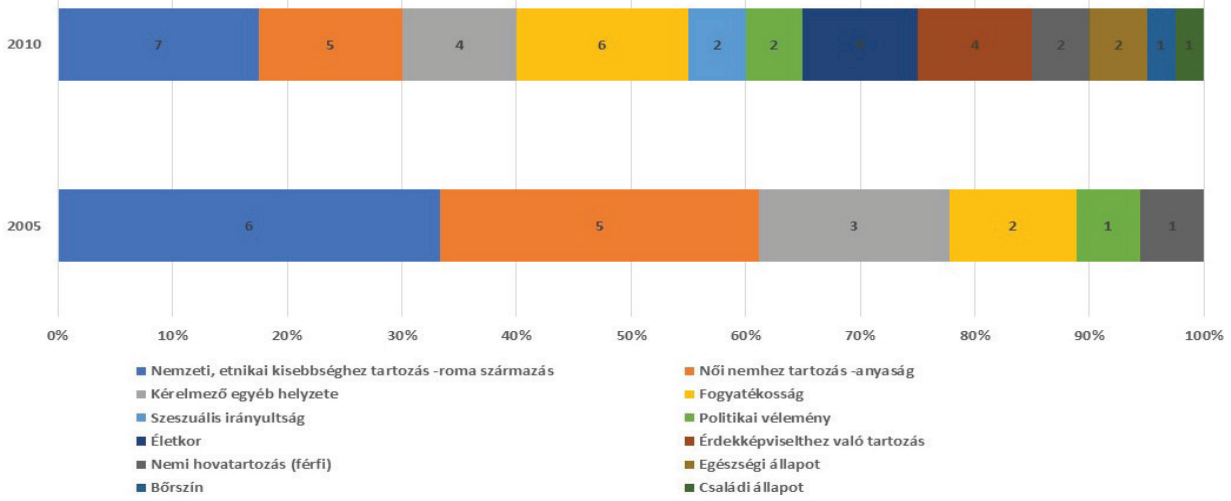

Forrás: Saját feldolgozás az EBH 2005. és 2010. évi jelentésének adatai alapján

A beérkezett panaszok döntő többsége 2010-ben is a munka világával összefüggésben született. A panaszosok a munkáltatók döntéseit sérelmezve, sok esetben védett tulajdonság hiányában is diszkriminációra hivatkozva kérték a Hatóság segítségét, illetőleg kezdeményezték az eljárást. A beadványokból jól kimutatható az a tendencia, hogy megítélésük szerint elsősorban a munkához való hozzájutás, az állásinterjú, illetve a munkaviszony vagy a foglalkoztatásra irányuló egyéb jogviszony megszüntetése esetében éri sérelem az Egyenlő Bánásmód Hatósághoz fordulókat. A Hatóság az összesen 40 jogsértést megállapító határozatának több mint felében munkaügyi diszkriminációt állapított meg.

2015-ben a panaszosak által megjelölt védett tulajdonságok 74 esetben a fogyatékosság, 64 esetben nemzetiséghez tartozás és 39 esetben az apaság/anyaság mint védett tulajdonság megsértése voltak.

\section{d) A foglalkoztatáshoz kapcsolódó jogsértések alakulása}

A 2010. évről szóló jelentés már bemutatja a kizárólag a foglalkozás terén bekövetkezett jogsértések elemzését is (erre a 2005. évi jelentés még nem tért ki, csak az összes jogsértést összesítette). 2010-ben a bejelentések alapján 23 jogsértést állapított meg a Hatóság a foglalkoztatás terén: 5 esetben az anyaság, 4 esetben más érdekképviselethez tartozás miatt történt jogsértés. 2 esetben történt jogsértés a nem, életkor, politikai vagy más vélemény, egyéb helyzet miatt. 1-1 esetben történt jog- 


\section{TEMATIKUS TANULMÁNYOK - A munkaerőpiac gazdasági-társadalmi kérdései}

sértés etnikai hovatartozás, szexuális irányultság, fogyatékosság, egészségi állapot, családi állapot és nemi identitás miatt.

A foglalkoztatás terén történt jogsértések 60,9\%-ban a munkaviszony ideje alatt, 26,1\%-ban a munkaviszony létesítésekor, 13\%-ban a munkaviszony megszűnésekor történtek.

A vizsgált esetek közül 2015-ben is a foglalkoztatások terén történt a legtöbb jogsértés (15 db), azonban 7 esetben a szolgáltatások (pl. akadálymentesítés hiánya) és 5 esetben a közszolgáltatások (önkormányzatok és szerveik hatáskörébe tartozó ügyek) terén is megállapított visszaélést a Hatóság.

A Hatóság minden évi jelentésében fontosnak tartja kiemelni a megegyezés fontosságát, miszerint nem „büntető”, sokkal inkább „prevenciós” és figyelmezteto szerepet kíván betölteni a panaszosok és a munkáltatók között és a megegyezésre törekszik. Mindhárom vizsgált jelentésben szerepel, hogy az EBH a nem a saját felelősségi körébe tartozó ügyek nagy részében is közvetítő szerepet vállal az intézkedésre jogosult állami, önkormányzati szervek és a panaszos között.

\section{Összegzés}

A tanulmányban az esélyegyenlőség és az egyenlő bánásmód foglalkoztatási aspektusainak bemutatására vállalkoztunk. Az áttekintés alapján látható, hogy az Európai Unió és hazánk nagy erőfeszítéseket tesz jogi és nem jogi eszközökkel annak érdekében, hogy a polgárokat ne érje hátrányos megkülönböztetés nemük, fajuk, fogyatékosságuk stb. alapján. Az esélyegyenlőség állampolgári jogát és fenntartását azonban nem csak az alapdokumentumok és irányelvek írják elő, hanem azt a gazdasági szükségesség is erősíti. Az esélyegyenlőség alapján biztosítható ugyanis, hogy a családjával és nemzetével harmonikusan élő, testileg és mentálisan egészséges, jól képzett ember nemcsak a demokrácia szempontjából fontos értékrend hordozója, hanem a XXI. századi modern nemzetgazdaság legfőbb erőforrása is lehessen.

A hazai tendenciák elemzése alapján az Egyenlő Bánásmód Hatóság éves jelentései azt igazolták, hogy a hozzájuk fordulók jelentős részének panaszai a munka világával, a foglalkoztatással összefüggő diszkriminációval - ezen belül is az álláskeresés során megnyilvánuló hátrányos megkülönböztetéssel - kapcsolatosak. A beadványokból jól kimutatható az a tendencia, hogy elsősorban a munkához való hozzájutás, az állásinterjú, és csak mindezek után a munkaviszony vagy a foglalkoztatásra irányuló egyéb jogviszony megszüntetése esetében éri sérelem az Egyenlő Bánásmód Hatósághoz fordulókat.

Az EBH jelentéseinek adatait vizsgálva ugyanakkor látható, hogy az egyenlő bánásmód követelményének megsértésével érintett társadalmi csoportok nagyságát nem lehet ténylegesen megítélni, illetve számszerűleg megbecsülni a beadott jogérvényesítési igényeik száma alapján. Az esetek többsége rejtve marad mind a 


\section{TEMATIKUS TANULMÁNYOK - A munkaerőpiac gazdasági-társadalmi kérdései}

hatóság, mind más jogérvényesítésben közreműködő szervek előtt, mivel a diszkrimináció sértettjei nem minden esetben rendelkeznek megfelelő érdekérvényesítő képességgel.

A Hatóság médiafelületeken való megjelenése, munkásságának tudatos népszerűsítése, a referens-hálózat létrehozása ugyanakkor óriási szerepet tölt be abban, hogy előtérbe kerüljön az emberek jogtudatos viselkedése. A honlapon és a kiadványaikban bemutatásra kerülő jogesetek gyakorlatilag mindenki számára érthetővé és világossá teszik, melyek azok az esetek, amelyekkel az emberek segítségért fordulhatnak hozzájuk az őket ért diszkrimináció esetén a foglalkoztatás, az áruk forgalma/szolgáltatások igénybevétele, az oktatás és az őket érintő egyéb ügyek terén. Tudatosítják továbbá azt is, melyek azok a jogesetek, amelyek a védett tulajdonságokkal nincsenek összefüggésben és nem az EBH hatáskörébe tartoznak

Összefoglalásként megállapíthatjuk, hogy a jogalkotó számos intézményt és szervezetet hozott létre és kapcsolt össze a területen, amelyek mindegyike az egyenlő esélyek biztosítása felett őrködik. A terület és az intézmények sokfélesége jól példázza, hogy mennyire komplex az esélyegyenlőségek témaköre. Az egyenlő esélyek biztosítása azonban nem csak az állam feladata: a jogalkotó abban a munkáltatók számára is kötelezettségeket ír elő, ugyanis csak közös társadalmi szerepvállalással valósítható meg az egyenlő bánásmód feltételeinek megteremtése.

\section{Irodalom}

Barakonyi, E. (2015): A tiltástól a követelményekig. Az Európai jogfejlődés főbb állomásai a hátrányos megkülönböztetéstől az egyenlő bánásmód követelményéig. Tudásmenedzsment, 2015/1., 38-50.

Cseres-Gergely, Zs. (2018): Jövedelemegyenlőtlenség Európában - Nők, férfiak és párok. In: Szabó-Morvai Ágnes (szerk.): Közelkép - Nők a munkaerőpiacon. Munkaerőpiaci tükör, 2017. Budapest, MTA Közgazdaság- és Regionális Tudományi Kutatóközpont Közgazdaságtudományi Intézet.

Cserné, A. G. (2006): A felnőttek foglalkoztathatóságának növelésére irányuló komplex képzési modellek, különös tekintettel a hátrányos helyzetű csoportokra, javaslatok, intézkedésekre. Kutatási Zárótanulmány. In: Felnőttképzési Kutatási Füzetek. Budapest, Nemzeti Felnőttképzési Intézet, 219.

Dajnoki, K. - Balázs - Földi, E. (2016): Diszkrimináció a munkerőpiacon. Közép-Európai Közlemények, 9 évf. 3., 150-165.

Farkas, T. - Kenderfi, M. - Suhajda, Cs. (2011): Esélyegyenlőség és tanácsadás. Szent István Egyetem, Gödöllő.

Garadnay, T. - Koltai, L. - Izványi, Á. - Dr. Ozvári, Á. (2009): Szöveggyűjtemény speciális helyzetű csoportokkal, egyénekkel előadáshoz. Esély, Budapest. 


\section{TEMATIKUS TANULMÁNYOK - A munkaerőpiac gazdasági-társadalmi kérdései}

Gregor, K. - Pásztor, M. (szerk.) (2016): Tájékoztató az Egyenlő Bánásmód Hatóság 2015. évi tevékenységéről, valamint az egyenlő bánásmódról és az esélyegyenlőség előmozdításáról szóló 2003. évi CXXV. törvény alkalmazásának tapasztalatairól. Egyenlő Bánásmód Hatóság, Budapest.

Gregor, K. - Pásztor, M. (szerk.) (2017): Tájékoztató az Egyenlő Bánásmód Hatóság 2016. évi tevékenységéről, valamint az egyenlő bánásmódról és az esélyegyenlőség előmozdításáról szóló 2003. évi CXXV. törvény alkalmazásának tapasztalatairól. Egyenlő Bánásmód Hatóság, Budapest.

Halmos, Cs. (2005): A felnőttképzésben résztvevők elhelyezkedése, különös tekintettel a hátrányos helyzetű rétegekre, régiókra. NFI, Budapest.

Hárs, Á. (2012): Atipikus foglalkoztatási formák Magyarországon a kilencvenes és a kétezres években. Budapest Munkagazdasági Füzetek, 2012/7., 186.

Jelentés az Egyenlő Bánásmód Hatóság tevékenységéről, valamint az egyenlő bánásmódról és az esélyegyenlőség előmozdításáról szóló 2003. évi CXXV. törvény alkalmazásának tapasztalatairól, 2006. július http://www.egyenlobanasmod. hu/app/webroot/files/img/articles/a097ff677094d7661483bf405dc4b309/ 2005beszamolo.pdf (Letöltés ideje: 2018. július 26.)

Juhász, I. - Maticsákné Lizák, M. (2014): Az esélyegyenlőségi terv szerepe a munka világában In: Emberi-erőforrás gazdálkodás. Eszterházy Károly Főiskola, Eger.

Kenderfi, M. (2012): Hátrányos helyzetű rétegek munkaerő-piaci integrációjának kérdései Beregszász járásban. In: Partnerség Határok Nélkül Projektbeszámoló. Magyar Ökomenikus Segélyszervezet, Budapest, 96.

Lipták, K. - Matiscsákné Lizák, M. (2018): A kisgyermekes nők foglalkoztatási helyzete és lehetőségeik. Vezetéstudomány., Budapest Management Review, 49 (3). 41-51.

Mihály, I. (2003): Lelki terror a munkahelyeken. Munkaügyi Szemle, 47. évf. 10. sz. 9- 10.

Neményi, M. - Ferencz, Z. - Laki, I. - Ságvári, B. - Takács, J. - Tardos, K. - Tibori, T. (2013): Az egyenlő bánásmóddal kapcsolatos jogtudatosság növekedésének elemzése 2010-2013 között. Egyenlő Bánásmód Hatóság, Budapest.

Neményi, M. - Ságvári, B. - Tardos, K. (2017): Az egyenlő bánásmóddal kapcsolatos jogtudatosság 2017. Budapest, MTA TKSZI, 41.

Niederfiringer, V. - Soltész, A. (2013): Az esélyegyenlőségi terv hatásának vizsgálata. Egyenlő Bánásmód Hatóság, Budapest, 109.

Őry, M. (2005): Hátrányos helyzetű csoportok a munkaerőpiacon. Nemzeti Felnőttképzési Intézet, Budapest.

Simonovits, B. - Koltai, J. (2013): A munkáltatók munkavállalói kiválasztási gyakorlata a diszkrimináció tükrében. Egyenlő Bánásmód Hatóság, Budapest. 
Tájékoztató az Egyenlő Bánásmód Hatóság 2010. évi tevékenységéről, valamint az egyenlő bánásmódról és az esélyegyenlőség előmozdításáról szóló 2003. évi CXXV. törvény alkalmazásának tapasztalatairól http://www.egyenlobanasmod. hu/app/webroot/files/img/articles/48c4e8aeaf0f9d326afa345ef57371b2/ 2010beszamolo3.pdf (Letöltés ideje: 2018. július 26.)

Tardos, K. (2015): Halmozódó diszkrimináció. Kirekesztés és integráció a munkaerőpiacon. Belvedere Meridionale, Szeged.

Visztenvelt, A. - Molnár, N. - Suhajda, Cs. J. (2014): The regional role of municipalities in the integration of disadvanteged groups. In: Monika Gubáňová (ed.): Legal, Economic, Managerial and Environmental Aspects of Performance Competencies by Local Authorities. Slovak University of Agriculture, Nitra, 1-8.

\section{Hivatkozott jogszabályok listája}

100. számú Egyezmény a férfi és a női munkaerőnek egyenlő értékű munka esetén járó egyenlő díjazása tárgyában. ILO, 1951

111. számú egyezmény a foglalkoztatásból és a foglalkozásból eredő hátrányos megkülönböztetés tárgyában. ILO, 1958

Magyarország Alaptörvénye

1997. évi CLIV. törvény az egészségügyről

2003. évi CXXV. törvény az egyenlő bánásmódról és az esélyegyenlőség előmozdításáról

2011. évi CXCI. törvény a megváltozott munkaképességű személyek ellátásairól és egyes törvények módosításáról

2012. évi I. törvény a Munka Törvénykönyvéről

A faji megkülönböztetés valamennyi formájának kiküszöböléséről szóló nemzetközi egyezmény. ENSZ, 1965

A fogyatékossággal élő személyek jogairól szóló nemzetközi egyezmény. ENSZ, 2008

A Tanács 2000/78/EK irányelve a foglalkoztatási és munkahelyi egyenlő bánásmód általános kereteinek a létrehozásáról.

Az Európai Unió Alapjogi Chartája. http://eur-lex.europa.eu/legal-content/HU/TXT /?uri=CELEX\%3A12012P\%2FTXT (Letöltés ideje: 2018. július 26.)

Az Európai Unió működéséről szóló szerződés egységes szerkezetbe foglalt változata (EUR-LEX) http://eur-lex.europa.eu/legal-content/HU/TXT/?uri=CELEX: 12016E157 (Letöltés ideje: 2018. július 26.)

Emberi Jogok Egyetemes Nyilatkozata. ENSZ, 1948 
www. metszetek.unideb.hu

TEMATIKUS TANULMÁNYOK - A munkaerőpiac gazdasági-társadalmi kérdései

Esélyegyenlőség és diszkrimináció-mentesség a kibővített Európai Unióban. Európai Bizottság, 2004

Európai Foglalkoztatási Stratégia https://ec.europa.eu/social/main.jsp?langId=hu\&catId=101\#navItem-relatedTopics (Letöltés ideje: 2018. július 26.) 